\title{
Effect of Turbo Charging on the Performance of Dual Fuel (DF) Engine Operated on Rice Bran Oil Methyl Ester (RBOME) and Coconut Shell Derived Producer Gas Induction
}

\author{
Nataraja KM ${ }^{1}$, Banapurmath $\mathrm{NR}^{2 *}$, Yaliwal VS ${ }^{3}$, Manavendra ${ }^{4}$, Akshay $\mathrm{PM}^{2}$ and Chetan Kulkarni ${ }^{2}$ \\ 1 J.S.S. Academy of Technical Education, Bangalore 560060, Karnataka, India \\ ${ }^{2}$ B.V.B College of Engineering and Technology, Hubli, Karnataka, India \\ ${ }^{3}$ S.D.M. College of Engineering and Technology, Dharwad 580 002, Karnataka, India \\ ${ }^{4}$ B.I.E.T. College of Engineering and Technology, Davangere, Karnataka, India
}

\begin{abstract}
Producer gas operated diesel/biodiesel dual fuel engines suffer from $20-30 \%$ derating due to lowered gas energy content and reduced volumetric efficiency. These drawbacks of dual fuel (DF) engines can be overcome by using a suitable turbocharger (TC) matched to the modified diesel engine. Concept of the turbo-charging is an attractive solution to considerably improve the performance with lower emissions for DF engines. In view of this, comprehensive experimental study was carried out on a diesel engine fitted with TC operated in DF mode using biodiesel of rice bran oil and producer gas derived from Coconut shell induction. From the study it is observed that DF engine could operate at higher loads of $3.33 \mathrm{~kW}$ (up to $90 \%$ load) compared to normal aspirated (NA) DF engine which operated at $2.96 \mathrm{~kW}(80 \%$ load). Results showed that the turbo-charging facilitated improved performance of TCDF at higher loads with maximum brake thermal efficiency of $22.5 \%$ and $10-25 \%$ reduced emissions of smoke, $\mathrm{HC}$ and $\mathrm{CO}$ compared to NADF engine.
\end{abstract}

Keywords: Dual fuel engines; Turbocharging; Biodiesel; Coconut shell biomass; Emissions; Combustion parameters

\section{Introduction}

Energy per capita of a country is an indication of country economy. The demand for energy is growing rapidly in India and for the rest of the world unlike due to increased economic growth. It is estimated that India's primary energy demand will increase from 750 Mtoe (million tons of oil equivalent) to 1258-1647 Mtoe between 2011 and 2035, Recent World Energy Outlook-2013 [1]. Power production from diesel engines are becoming more and more popular because of their higher brake thermal efficiency, power output, and reliability, lesser fuel consumption, lower emissions and durability. Hence diesel engine technology plays a vital role in transportation, agricultural and power generation applications. Energy conservation with high efficiency and low emissions are important research topics for engine design and development. It is estimated that the oil demand in India is nearly about 3 million barrels / day and will reach more than 8 million barrels per day in 2035 (IEA, 2013) [2]. The deficiency is met through imports of nearly 172 million tons of crude petroleum products that cost the country close to US $\$ 158$ billion in 2011-12 (Ministry of petroleum and natural gas-2012). Increased pollution, depletion nature and volatile oil prices and the uncertainty about sustained oil supplies have led India to extensive search for alternative fuels through complete utilization of renewable energy. In this regard India is set many facilitating policies towards renewable energy. Hence energy derived from renewable sources can not only reduce the dependency on imported oil, but resulted in numerous advantages compared to fossil fuels as they are renewable and biodegradable besides providing energy security and foreign exchange saving addressing environmental concerns, and socio-economic issues as well $[3,4]$. In this context, biofuels such as biodiesels of different origin and producer gas are considered among the most promising alternative options, as they can be produced locally and can be substituted for diesel and petrol to meet the power generation and transportation sector requirements. The interest in biofuels in the industrialized countries, apart from promoting energy security, is also aimed at supporting agriculture and rural development and mitigating the threat of climate change by replacing fossil fuels with renewable sources [5]. Of the total emission load in the world, about more than $50 \%$ emissions are from transport sector. In view of this several researchers reported that biofuels have a large potential to reduce greenhouse gas (GHG) emissions with acceptable performance from the diesel engine. On the other hand, developing countries such as India have multiple constraints in promoting Biofuels, such as promoting energy security, rural development, and the reclamation of degraded lands as well as coping with the challenges of land and water scarcity and improving food security.

Energy conservation with high efficiency and low emission are important research topics for engine design and development. In this regard, dual fuel engines with turbo charging resulted in improved power output with reduced emission levels [6]. Several researchers have reported that dual fuel (DF) engines are best suited for power generation applications; because they are able to comply with the NO emission limits. However, the performance of today's established DF designs is limited mainly by the phenomenon of decreased combustion efficiency. However, DF engines with turbo charging, can address this limitation set and achieve reasonable efficiency and power density. Additionally, DF operation also suffers from lower volumetric

*Corresponding author: Banapurmath NR, Department of Mechanical Engineering, B. V. B. College of Engineering and Technology, Hubli 580 031, Karnataka, India, Tel: +919880726748, Fax: +918362374985; E-mail: nr_banapurmath@rediffmail.com

Received March 03, 2015; Accepted March 30, 2015; Published April 07, 2015

Citation: Khandal SV, Banapurmath NR, Yaliwal VS, Manavendra G, Akshay PM et al. (2015) Effect of Turbo Charging on the Performance of Dual Fuel (DF) Engine Operated on Rice Bran Oil Methyl Ester (RBOME) and Coconut Shell Derived Producer Gas Induction. J Pet Environ Biotechnol 6: 216. doi:10.4172/21577463.1000216

Copyright: (c) 2015 Khandal SV, et al. This is an open-access article distributed under the terms of the Creative Commons Attribution License, which permits unrestricted use, distribution, and reproduction in any medium, provided the original author and source are credited. 
Citation: Khandal SV, Banapurmath NR, Yaliwal VS, Manavendra G, Akshay PM, et al. (2015) Effect of Turbo Charging on the Performance of Dual Fuel (DF) Engine Operated on Rice Bran Oil Methyl Ester (RBOME) and Coconut Shell Derived Producer Gas Induction. J Pet Environ Biotechnol 6: 216. doi:10.4172/2157-7463.1000216

Page 2 of 7

efficiency. Sufficient utilization of air during combustion of fuel combination is a key factor to increase power density and efficiency of engines operating according to the diesel cycle. The occurrence of lower combustion efficiency can have many reasons, for instance low methane number of the producer gas, insufficient homogeneity of the in-cylinder charge, cylinder-to-cylinder or cycle-to cycle variability of the charge composition, deposits, unfavorable pressure-time history in the bulk of the unburned gas of the cylinder charge, etc. [7]. Residence time of the unburned gas with their lower pressure and temperature leads to increased loss of combustion efficiency. The DF engine with producer gas induction has been found to result in higher thermal efficiency with reduced emission levels at a higher CR and advanced IT. Producer gas-fuelled DF engine has been reported to result in a lower BTE and a higher exhaust gas temperature (EGT) [3,4,8-11]. However, a small increment in BTE has been observed for advanced injection timing and an increased compression ratio. Several investigators have observed increased hydrocarbon (HC) and carbon monoxide (CO) emission levels for a dual-fuel mode of operation [3,4,10-14]. The effect of pilot fuel injection, injection timing and injection pressure on the performance and exhaust emission levels of a supercharged producer gas-diesel-fuelled dual-fuel engine has been investigated. Better engine performance was reported with higher injection pressures than lower ones. Higher nitric oxide emission levels have been found at maximum power conditions $[14,15]$.

The higher octane number of producer gas allows the use of a higher CR without engine knocking. For a given excess air using single stage turbo charging results in improved in-cylinder cycle temperatures which enables an increase of the compression ratio or/and the power density. However, for maintaining a constant air excess ratio, the charge air pressure needs to be raised to a higher level. Only mode rate levels of turbo charging can be realized because of the limited pressure levels that can be achieved with single stage turbo charging. Because of the constraints imposed by the producer gas mode operation, engine efficiency suffers especially in DF mode. Diesel engines operating on DF mode use the available charge pressure to achieve lower brake thermal efficiency of roughly $15-17 \%$ at an advanced injection timing, increased injection pressure and compression ratio.

A theoretical understanding of the combustion and gasification has made a significant progress during the past decades. However, a negative point concerning producer gas fuelled DF engines have always been the necessity of constant monitoring and fine tuning in order to achieve satisfactory performance with reduced emission levels. In view of this major attention and interest is given to enhance the thermal efficiency of a producer gas-operated DF engine with decreased emission levels by utilization of single stage turbo charging. The objective of this study is to investigate the potential of high-load, turbo-charged, diesel engine operated on DF mode using RBOME and Coconut shell derived producer gas (CSPG) induction and to discuss how the turbo charging affects the performance, combustion and emission levels. The performance and emissions of the turbocharged DF engine under all loads are compared with conventional DF engine.

\section{Characterization of Fuels Used}

Rice bran oil methyl ester (RBOME) was derived from Rice washing and producer gas by partial combustion of woody biomass in a downdraft gasifier. The properties of the fuels were determined in the laboratory. Table 1 shows the properties of liquid fuels and proximate and ultimate analysis of biomass feed stock used in the present study. The composition of producer gas derived from coconut shell is shown in Table 2.

\section{Experimental Setup}

Experiments were conducted on a Kirloskar TV1 type, four stroke, single cylinder, water-cooled diesel engine test rig. Figure 1 shows the experimental set up along with TC arrangement. The inlet manifold was suitably modified to accommodate TC for the single cylinder engine. The pulsating air supply to the engine was stabilized by providing a chamber of increased cross sectional area close to the inlet of the engine. This helped in stabilizing the engine speed as well. Eddy current dynamometer was used for loading the engine. The fuel flow rate was measured on the volumetric basis using a burette and stopwatch. The engine was operated at a rated constant speed of $1500 \mathrm{rev} / \mathrm{min}$. The down draft gasifier was suitably connected to the engine with filter and cooling and cleaning system. Producer gas was generated using a downdraft gasifier. The gas is taken inside the combustion chamber by the suction of the engine. The gas flow was measured using a calibrated venturimeter provided with digital gas flow meter. Cooling of the engine was accomplished by circulating water through the jackets of the engine block and cylinder head. The cylinder pressure was measured using a Piezo electric transducer fitted in the cylinder head as shown in Figure 2. A $45^{\circ}$ flow gas entry carburetor for producer gas induction was fitted to the inlet manifold of the engine

\begin{tabular}{|c|c|c|c|c|c|c|}
\hline SI.No & Properties & Diesel & Rice Bran oil & RBOME & Description & Coco-Nut shell \\
\hline 1 & Viscosity @ 40ㄷ (cst) & 3.5 & 32.6 & 4.12 & Moisture Content, \% w/w & 9.2 \\
\hline 2 & Flash point ${ }^{\circ} \mathrm{C}$ & 56 & 316 & 174 & Ash Content, \% w/w & 2.1 \\
\hline 3 & Calorific Value in $\mathrm{kJ} / \mathrm{kg}$ & 45000 & 40106 & 41106 & Volatile Matter, $\%$ w/w & 67.2 \\
\hline 4 & Density $\mathrm{Kg} / \mathrm{m}^{3}$ & 840 & 920 & 880 & Sulphur, \% w/w & 0 \\
\hline 5 & Cetane Number & 44 & 50 & 51 & Nitrogen, as $\mathrm{N} \% \mathrm{w} / \mathrm{w}$ & 0.30 \\
\hline 6 & Cloud point $\left({ }^{\circ} \mathrm{C}\right)$ & 6 & 13 & 9 & Fixed Carbon \% w/w & 19 \\
\hline 7 & Pour point $\left({ }^{\circ} \mathrm{C}\right)$ & -7 & 1 & -2 & $\begin{array}{l}\text { Gross Calorific value, } \\
\mathrm{kJ} / \mathrm{kg}\end{array}$ & 20490 \\
\hline 8 & Carbon residue $(\%, w / w)$ & 0.1 & 0.6 & 0.35 & Density, kg/ m³ & 404 \\
\hline 9 & ----- & ---- & & ----- & Phosphorus $\%$ w/w & --- \\
\hline 10 & Type of oil & Fossil & Non edible & Non edible & Potassium & --- \\
\hline
\end{tabular}

Table 1: Properties of liquid fuels and Proximate and ultimate analysis of biomass feed stocks.

\begin{tabular}{|c|c|c|c|c|c|c|c|c|c|}
\hline Type of wood & $\mathrm{CO} \%$ & $\mathrm{H}_{2} \%$ & Methane \% & HC \% & $\mathrm{N}_{2} \%$ & $\begin{array}{c}\text { Water Vapour } \\
\%\end{array}$ & $\mathrm{CO}_{2} \%$ & $\begin{array}{c}\text { Calorific value } \\
{\mathrm{MJ} / \mathrm{Nm}^{3}}^{3}\end{array}$ & Density $\mathrm{kg} / \mathrm{m}^{3}$ \\
\hline Coco-Nut shell & $17-23 \%$ & $16-21 \%$ & $1-6 \%$ & $0.3-0.5 \%$ & $4.2-5.4 \%$ & 4 & $8-10 \%$ & 5.2 & $1.22-1.27$ \\
\hline
\end{tabular}


Citation: Khandal SV, Banapurmath NR, Yaliwal VS, Manavendra G, Akshay PM, et al. (2015) Effect of Turbo Charging on the Performance of Dual Fuel (DF) Engine Operated on Rice Bran Oil Methyl Ester (RBOME) and Coconut Shell Derived Producer Gas Induction. J Pet Environ Biotechnol 6: 216. doi:10.4172/2157-7463.1000216
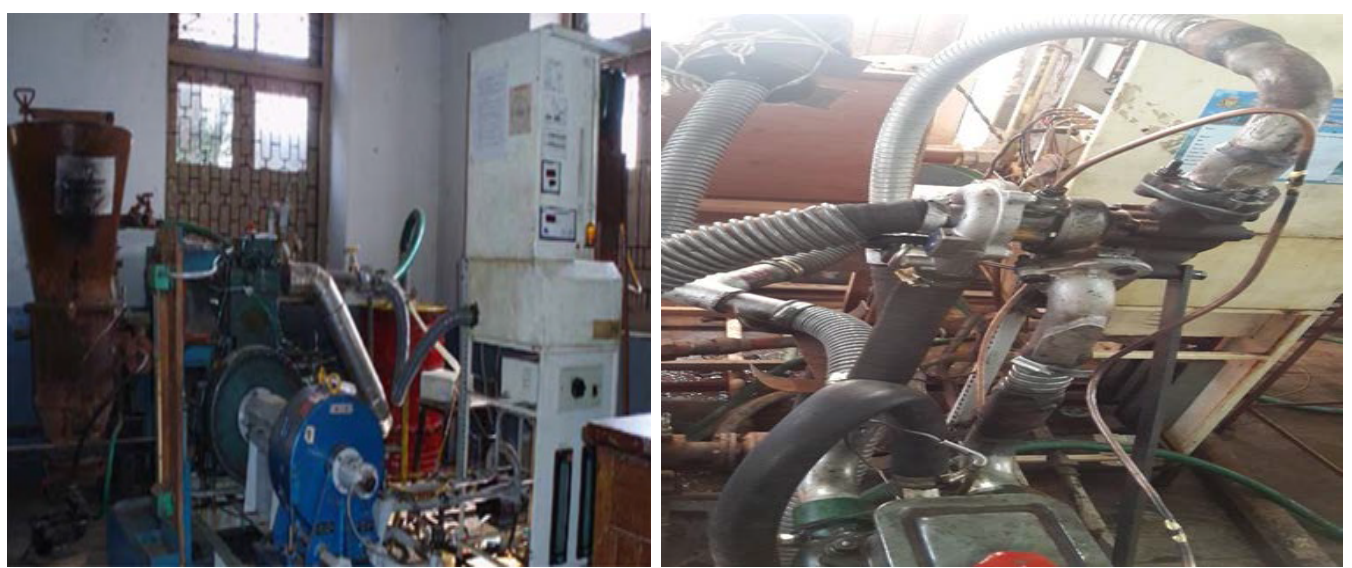

Figure 1: Overall view of Experimental Setup with and without Turbocharger.
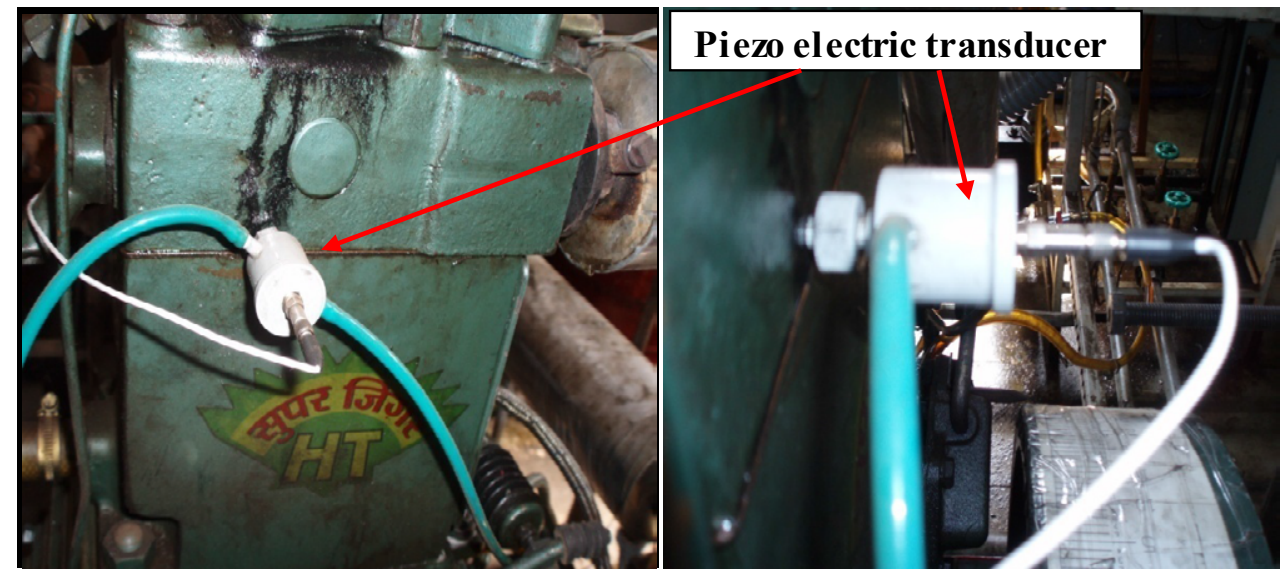

Figure 2: Views of Pressure Sensor fitted to engine cylinder.

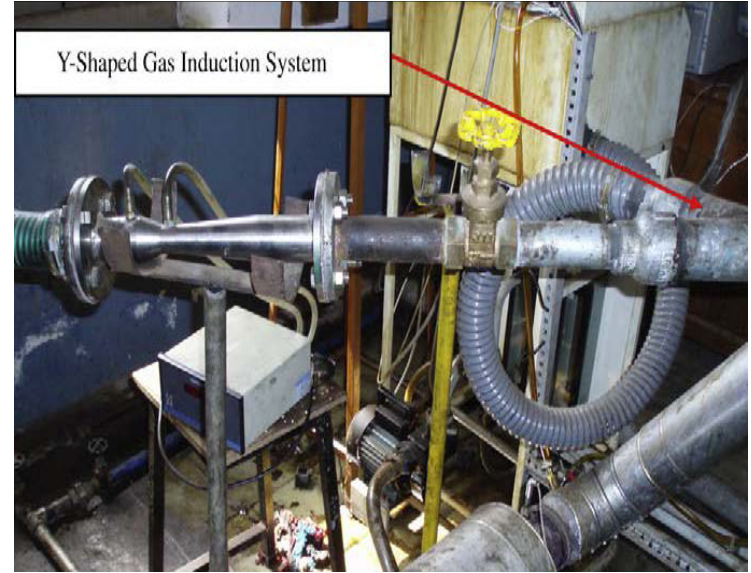

Figure 3: $45^{\circ}$ flow gas entry carburetor with venture adopted before and after engine operation

as shown in Figure 3. In the present work, amount/quantity of both injected fuels of Diesel and RBOME have been measured on volumetric basis. At fixed brake power more amount of RBOME is injected as its calorific value is comparatively lower and also its kinematic viscosity is higher (nearly twice diesel). This is done by adjusting the governor speed so that constant speed is maintained in both the versions of the injected fuels. The emission characteristics were measured by using HARTRIDGE smoke meter and five gas analyzer during the steady state operation. During the complete experimentation, the gas flow rate and engine speed were maintained constant. For the present work, injection timing of $27^{\circ} \mathrm{bTDC}$, 4-hole injector of $0.2 \mathrm{~mm}$ orifice with injector opening pressure of $230 \mathrm{bar}$ and compression ratio at 17.5 were maintained. Experiments were conducted by using RBOME-producer gas combination using toroidal combustion chamber (TCC) shape. Finally the results obtained with RBOME-producer gas operation was compared with diesel-producer gas operation. The specification of the compression ignition (CI) engine and down draft gasifier is given in Table 3. For each load, five readings were generated to ensure the accuracy of the data recorded and careful experimental arrangements were made to obtain consistent and repeatable measurements.

\section{Results and Discussions}

In this section effect of single stage turbo charging on the performance of dual fuel engine has been presented. Comparative assessment of DF engine by identifying suitable TC and intake manifold design is a special feature of this study. Experiments were conducted by using selected fuel combinations with NADF engine of manufacturer settings (23 BTDC, 205 bar, 3 hole injector of 0.3 $\mathrm{mm}$ orifice, hemispherical combustion chamber) and optimized parameters $\left(27^{\circ} \mathrm{BTDC}, 230 \mathrm{bar}, 4\right.$ hole injector of $0.3 \mathrm{~mm}$ orifice, toroidal combustion chamber) and finally TCDF engine. Analysis of 
Citation: Khandal SV, Banapurmath NR, Yaliwal VS, Manavendra G, Akshay PM, et al. (2015) Effect of Turbo Charging on the Performance of Dual Fuel (DF) Engine Operated on Rice Bran Oil Methyl Ester (RBOME) and Coconut Shell Derived Producer Gas Induction. J Pet Environ Biotechnol 6: 216. doi:10.4172/2157-7463.1000216

Page 4 of 7

\begin{tabular}{|c|c|c|c|c|}
\hline \multirow{2}{*}{ SI No } & \multicolumn{2}{|r|}{ Compression ignition engine } & \multicolumn{2}{|c|}{ Down draft gasifier } \\
\hline & Parameters & Specification & Parameters & Specification \\
\hline 1 & Machine Supplier & Apex Innovations Pvt Ltd, Sangli. Maharastra State. & Rated capacity & $15000 \mathrm{kcal} / \mathrm{hr}$ \\
\hline 2 & Engine Type & $\begin{array}{c}\text { Single cylinder four stroke water cooled direct injection TV1 } \\
\text { compression ignition engine with a displacement volume of } 662 \mathrm{cc} \text {, } \\
\text { compression ratio of } 17: 1 \text {, developing } 5.2 \mathrm{~kW} \text { at } 1500 \mathrm{rev} / \mathrm{min} \text { TV1 ( } \\
\text { Kirolsker make) }\end{array}$ & Rated gas flow & $15 \mathrm{Nm}^{3} / \mathrm{hr}$ \\
\hline 3 & Software used & Engine Soft & $\begin{array}{l}\text { Average gas calorific } \\
\text { value }\end{array}$ & $1000 \mathrm{kcal} / \mathrm{m}^{3}$ \\
\hline 4 & Nozzle opening pressure & 200-225 bar & $\begin{array}{l}\text { Rated woody biomass } \\
\text { consumption }\end{array}$ & $5-6 \mathrm{~kg} / \mathrm{hr}$ \\
\hline 5 & Governor type & Mechanical centrifugal type & Hopper storage capacity & $40 \mathrm{~kg}$ \\
\hline 6 & Cylinder diameter (Bore) & $0.0875 \mathrm{mtr}$ & Biomass size & $\begin{array}{l}10 \mathrm{~mm} \text { (Minimum) } \\
50 \mathrm{~mm} \text { (Maximum) }\end{array}$ \\
\hline 7 & Stroke length & $0.11 \mathrm{mtr}$ & Moisture content (DB) & 5 to $20 \%$ \\
\hline 8 & Combustion camber & Open Chamber (Direct Injection) with hemispherical cavity & $\begin{array}{l}\text { Typical conversion } \\
\text { efficiency }\end{array}$ & $70-75 \%$ \\
\hline 9 & $\begin{array}{l}\text { Eddy current } \\
\text { dynamometer: }\end{array}$ & $\begin{array}{c}\text { Model :AG - } 10,7.5 \mathrm{KW} \text { at } 1500 \text { to } 3000 \mathrm{RPM} \text { and Water flows } \\
\text { through dynamometer during the use }\end{array}$ & & \\
\hline
\end{tabular}

Table 3: Specification of experimental test rig.

results obtained from the preliminary engine testing is summarized in the following sections.

Variation in brake thermal efficiency (BTE) with different loads is shown in Figure 4. The BTE peaks were found to be 19.88, 18.2\% and $14.44 \%$ for RBOME+PG (TC), RBOME + PGat optimized conditions and $\mathrm{RBOME}+\mathrm{PG}$ at manufacturer setting, respectively compared to $21.12 \%$ for diesel $+\mathrm{PG}$ (TC) operation at $80 \%$ load. Results showed that $\mathrm{RBOME}+\mathrm{PG}$ operation with turbocharged (TC) condition is comparable to that of diesel+PG (TC) operation. It is observed that turbo charging with optimized conditions, diesel $+\mathrm{PG}$ (TC) and RBOME+PG (TC) operation with extended load of 90\% (3.33 kW) and boosted the efficiency by $4.24 \%$ compared to the RBOME+PG operation with manufacturer setting and optimized conditions. With turbo charging, the dual fuel engine fails to operate at full load due to lower energy content of the inducted gas. It could also be due to turbo lag caused by power derating with producer gas fuel. Increased thermal efficiency with turbocharging is mainly due to reduced power derating and increased pressure supply of the air to the gas ensures improved air-gas mixing. Also more quantity of oxygen available for combustion may also be responsible for this observed trend. However in the present work, pump losses may limit the efficiency and is not addressed.

Variation in smoke opacity with different loads is shown in Figure 5. The smoke levels were found to be 46, $54 \mathrm{HSU}$ and $68 \mathrm{HSU}$ for $\mathrm{RBOME}+\mathrm{PG}$ (TC), $\mathrm{RBOME}+\mathrm{PG}$ at optimized conditions and $\mathrm{RBOME}+\mathrm{PG}$ at manufacturer setting, respectively compared to 38 HSU for diesel +PG (TC) operation at $80 \%$ load. The smoke emission for RBOME-PG operation with manufacturer and optimized setting is higher compared to diesel-PG operation due to higher viscosity and lower calorific value of RBOME than diesel-PG (TC) fuel. The most possible reason for higher smoke emission is due to the reduced soot oxidation caused by replacement of air by producer gas. Presence of higher free fatty acids in RBOME due to high viscosity of RBOME is also responsible for this trend. The higher the viscosity, the more difficult it is to atomize for the RBOME oil, hence resulted in locally rich mixtures in the combustion chamber. Since the producer gas is used in the dual fuel mode, more smoke emission was generated during the combustion process due to insufficient supply of oxygen. The main technical problems of gas combustion are to maintain the mixture inside the flammability limits to make sure that it will be leading to better combustion. However, lower smoke was observed for RBOMEPG operation with TCDF mode. This could be due to sufficient oxygen made available for the combustion. The flame temperature and oxygen availability is very important for the control of smoke emissions and therefore the dual fuel mode of operation with turbocharger gives slightly better combustion and less soot due to more oxygen available for the combustion.

Variation in hydrocarbon (HC) and carbon monoxide (CO) emission levels with different loads is shown in Figures 6 and 7. The $\mathrm{HC}$ levels were found to be 51, $56 \mathrm{ppm}$ and $61 \mathrm{ppm}$ for RBOME+PG (TC), RBOME+PG at optimized conditions and $\mathrm{RBOME}+\mathrm{PG}$ at manufacturer setting, respectively compared to $41 \mathrm{ppm}$ for diesel $+\mathrm{PG}$ (TC) operation at $80 \%$ load. Similarly CO levels were found to be 0.4 , $0.45 \%$ and $0.48 \%$ for $\mathrm{RBOME}+\mathrm{PG}$ (TC), RBOME+PG at optimized conditions and $\mathrm{RBOME}+\mathrm{PG}$ at manufacturer setting, respectively compared to $0.38 \%$ for diesel $+\mathrm{PG}$ (TC) operation at $80 \%$ load. The $\mathrm{HC}$ and $\mathrm{CO}$ emissions for RBOME-PG operation with manufacturer and optimized setting is higher compared to diesel-PG operation due to incomplete combustion caused by the higher viscosity of RBOME than diesel-PG (TC) fuel, lower air-fuel ratio and lower combustion temperature. The most possible reason for higher $\mathrm{CO}$ emission is due to the already presence of $\mathrm{CO}$ in the producer gas and reduced hydrocarbon oxidation caused by replacement of air by producer gas. Presence of higher free fatty acids in RBOME due to high viscosity of RBOME oil is also responsible for this trend. Producer gas fueled dual fuel engine, has higher $\mathrm{HC}$ and $\mathrm{CO}$ emissions generated during the combustion process due to incomplete combustion of both RBOME and producer gas and insufficient supply of oxygen. However, lower $\mathrm{HC}$ and CO levels were observed for RBOME-PG operation with turbo-charger. This could be due to sufficient oxygen available for the combustion leading to better combustion. The flame temperature and oxygen availability is very important for the control of hydrocarbon combustion and therefore the dual fuel mode of operation with turbocharger resulted in slightly better combustion and less $\mathrm{HC}$ and $\mathrm{CO}$ levels were observed due to more oxygen available for the combustion.

Effect of turbocharger on the nitric oxide $\left(\mathrm{NO}_{\mathrm{x}}\right)$ emission is presented in the Figure 8. The $\mathrm{NO}_{\mathrm{x}}$ emission levels were found to be 85 , $70 \mathrm{ppm}$ and $65 \mathrm{ppm}$ for RBOME+PG (TC), RBOME+PG at optimized conditions and $\mathrm{RBOME}+\mathrm{PG}$ at manufacturer setting, respectively compared to $105 \mathrm{ppm}$ for diesel $+\mathrm{PG}$ (TC) operation at $80 \%$ load. 
Citation: Khandal SV, Banapurmath NR, Yaliwal VS, Manavendra G, Akshay PM, et al. (2015) Effect of Turbo Charging on the Performance of Dual Fuel (DF) Engine Operated on Rice Bran Oil Methyl Ester (RBOME) and Coconut Shell Derived Producer Gas Induction. J Pet Environ Biotechnol 6: 216. doi:10.4172/2157-7463.1000216

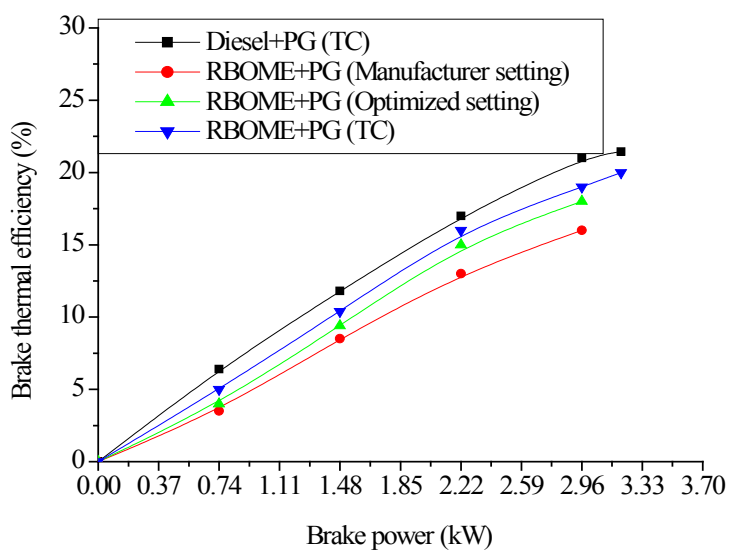

Figure 4: Variation of brake thermal efficiency with brake power.

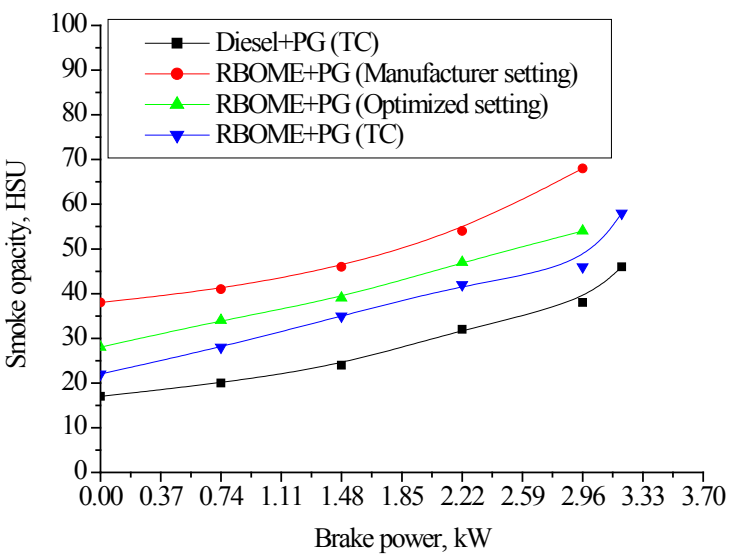

Figure 5: Variation of smoke opacity with brake power.

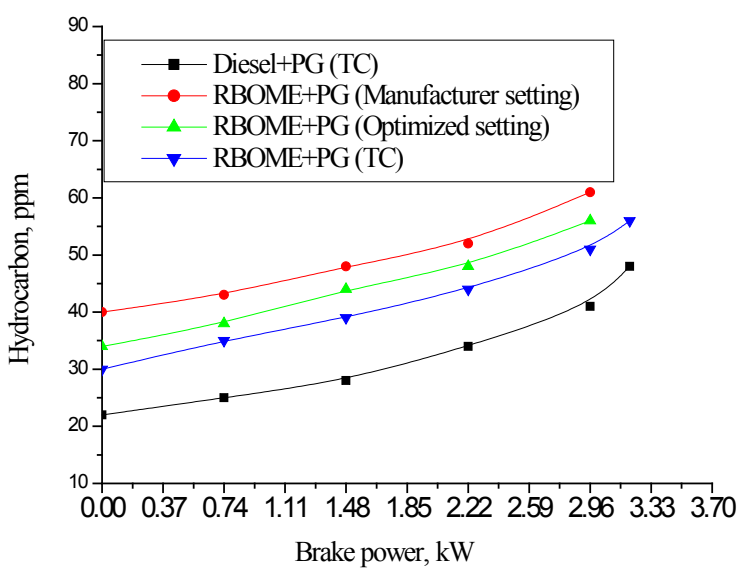

Figure 6: Variation of hydrocarbon emission with brake power

The $\mathrm{NO}_{\mathrm{x}}$ emission for RBOME-PG operation with manufacturer and optimized setting is lower compared to diesel-PG operation due to lower combustion temperature and less oxygen available for combustion. Lower combustion temperature is mainly caused by the lower heat release rate during premixed combustion phase. It could be attributed to higher viscosity and lower calorific value of both RBOME and producer gas than diesel-PG (TC) fuel combination. Since the producer gas is used in the dual fuel mode, lesser $\mathrm{NO}_{\mathrm{x}}$ emission was generated during the combustion process due to lower heat release rate. However, higher $\mathrm{NO}_{\mathrm{x}}$ was observed for RBOME-PG operation with turbo-charger. This could be due to more oxygen induction for the combustion. The flame temperature of fuel used associated with its physico-chemical properties and oxygen availability is very important for the control of $\mathrm{NO}_{\mathrm{x}}$ emissions and therefore the dual fuel mode of operation with turbocharger gives slightly better combustion leading to higher $\mathrm{NO}_{\mathrm{x}}$ emission levels.

\section{Combustion Parameters}

Turbo charging facilitate more air to be supplied for the combustion of fuel combinations used and this will have a bearing on the combustion parameters.

\section{Ignition Delay}

The variation of ignition delay with power output for turbocharging conditions is shown in Figure 9. With the turbocharging more amount of air enters into the chamber which increases the combustion process and reduces the ignition delay. It is concluded that there is a reduction of 6.20 CA for the turbocharged engine compared to normal engine at rated load. Hence it will be beneficial to increase the turbocharging pressures in order to have a shorter ignition delays. increased mass flow rate of air, reduces the ignition delay and the hotter combustion chamber further increases the combustion process.

This is further substantiated with combustion duration variation (Figure 10), in which the TC engine has lowered combustion duration compared to that without turbocharger.

\section{Peak Pressure Variation}

Figure 11 shows in-cylinder pressure variation versus crank angle for RBOME-producer gas combinations at $80 \%$ load for NADF (manufacturing and optimized settings) and TCCF. The peak pressures of normal engine, and turbocharged engines are compared in the Figure.

The peak pressure is governed by the combustion rate and the amount of fuel consumed during rapid combustion period. The uncontrolled combustion phase is further governed by the delay period and by the fuel mixture preparation during the delay period. Therefore, mixture preparation resulting and the associated slow burning nature of producer gas during the ignition delay period are responsible for the variations of peak pressure and maximum rate of pressure rise.

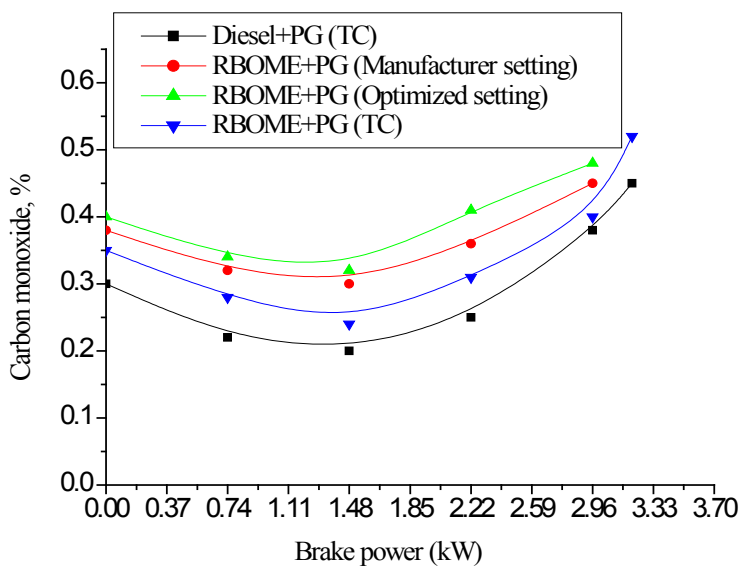

Figure 7: Variation of carbon monoxide with brake power. 
Citation: Khandal SV, Banapurmath NR, Yaliwal VS, Manavendra G, Akshay PM, et al. (2015) Effect of Turbo Charging on the Performance of Dual Fuel (DF) Engine Operated on Rice Bran Oil Methyl Ester (RBOME) and Coconut Shell Derived Producer Gas Induction. J Pet Environ Biotechnol 6: 216. doi:10.4172/2157-7463.1000216

Page 6 of 7

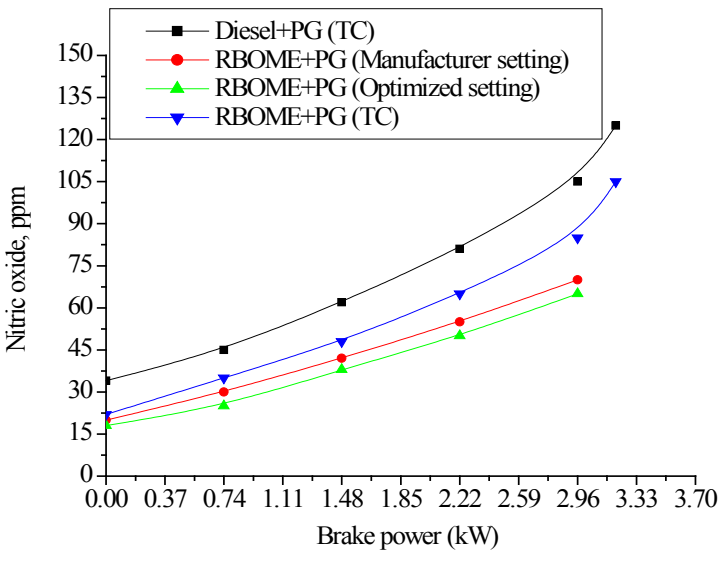

Figure 8: Variation of nitric oxide with brake power.

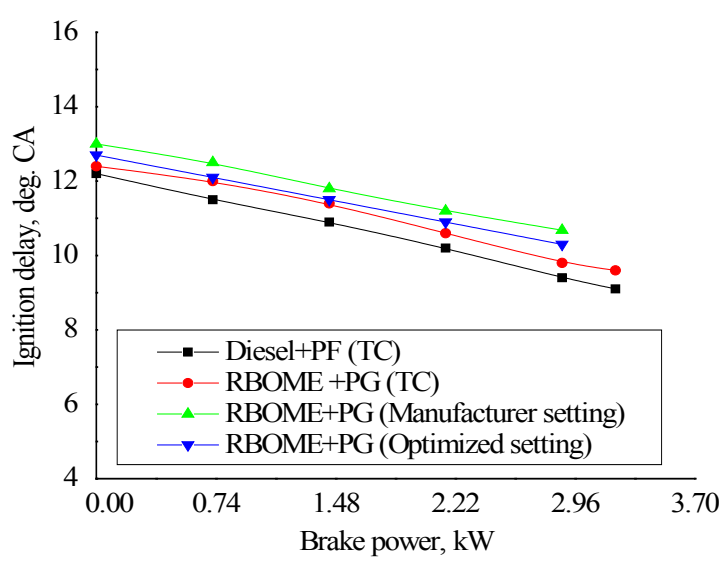

Figure 9: Variation of Combustion duration with power output.

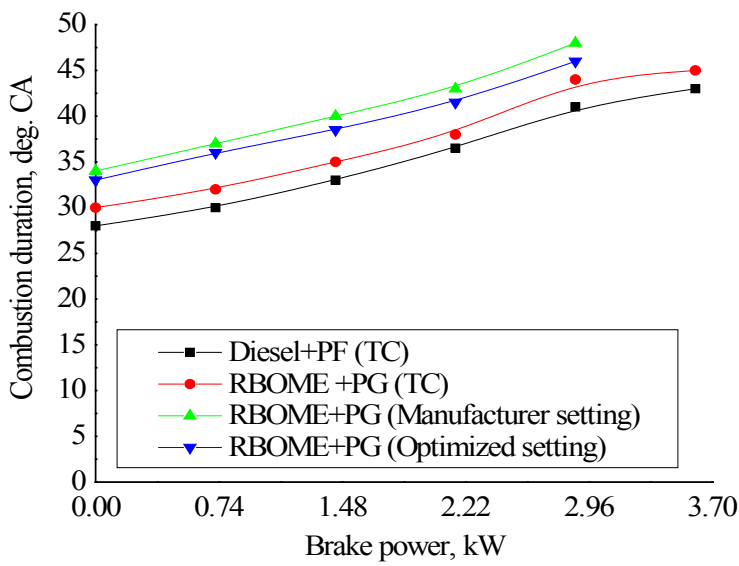

Figure 10: Variation of Combustion duration with power output

It is observed that the peak pressures are higher with turbocharged engine and is about 82 bar at the rated load. RBOME-producer gas with TCDF results in higher peak pressure compared to that at optimized and manufacture setting as shown in Figure 9. Turbocharging results in increased air-producer gas mixture density and increases the volumetric efficiency and the compression ratio. This in turn facilitates faster combustion and thus rapid pressure increase due to better fuel spray atomization and mixing. The NADF suffers from power de-rating as reported by several investigations on producer gas dual fuel engines. Also, poor quality of producer gas and reduction of air entrainment and fuel air mixing rates along with slow burning nature of producer gas in NADF engine are also responsible for these trends. However the NADF with optimized engine operating conditions shoes marginally higher peak pressure compared to manufacturing setting.

Figure 12 shows heat release rate versus crank angle for RBOMEproducer gas combinations at $80 \%$ load for NADF (manufacturing and optimized settings) and TCDF. RBOME - producer gas operation with NADF results in lower heat release rate compared to the TCDF. Higher heat release rate was observed for TCDF operation showing amore rapid combustion and concentrated heatrelease process, while flatter and broader heat release shapes were observed for NADF (manufacturing and optimized settings). Lower heat release rate resulted in lower pressure-rise rate, which benefits noise reduction.

\section{Conclusions}

Some important findings on the engine performance and environmental aspects under the dual-fuel mode of operation while using the producer gas derived from the coconut shell derived and RBOME as the injected fuel were made from the present study.

- Biomass gasification offers the most attractive alternative energy system for transport, agricultural and power generation applications.

- Operation of the RBOME and gasifier-engine system with suitable modifications makes the system completely independent from fossil fuels. RBOME can be used with producer gas induction under a dual-fuel mode.

- Dual fuel operation with renewable fuels such as non-edible oils and gaseous fuel derived from biomass is the best solution

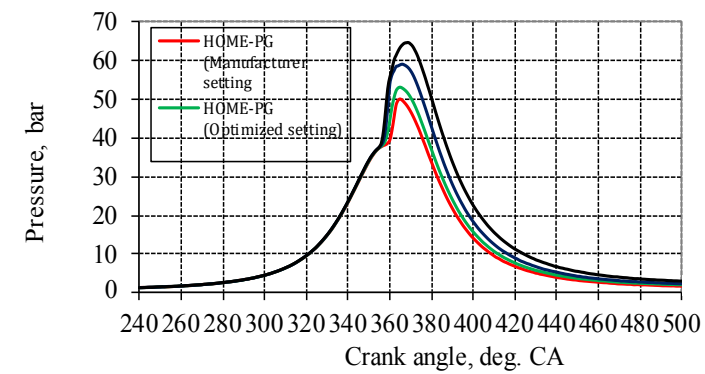

Figure 11: In-cylinder Pressure Versus Crank Angle for dual fuel engine at $80 \%$ Load.

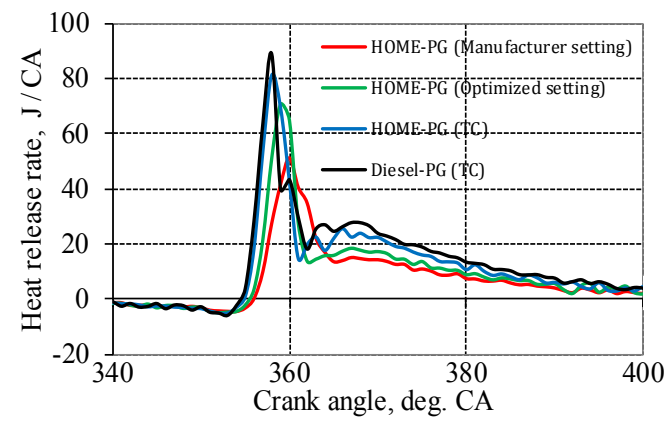

Figure 12: Heat release rate versus crank angle for dual fuel engine at $80 \%$ Load. 
Citation: Khandal SV, Banapurmath NR, Yaliwal VS, Manavendra G, Akshay PM, et al. (2015) Effect of Turbo Charging on the Performance of Dual Fuel (DF) Engine Operated on Rice Bran Oil Methyl Ester (RBOME) and Coconut Shell Derived Producer Gas Induction. J Pet Environ Biotechnol 6: 216. doi:10.4172/2157-7463.1000216

for providing decentralized electricity to remote unelectrified villages.

- Results on the integrated gasifier-engine system favoured a turbo-charging as such dual fuel engines suffer from reduced engine performance.

- TFDC operated with RBOME-PG showed increased BTE, reduced emissions of smoke, $\mathrm{HC}$ and $\mathrm{CO}$ while $\mathrm{NO}_{\mathrm{x}}$ increased compared to NADF engine in both versions of manufacturer and optimized engine conditions.

- Peak pressure and heat release rates were higher in TFDC engine compared to NADF engine.

\section{References}

1. World Energy Outlook 2014.

2. IEA-2013.

3. Banapurmath NR, Yaliwal VS, Satish K, Hunashyal AM, Tewari PG (2011) Effect of Wood Type and Carburetor on the Performance of Producer GasBiodiesel Operated Dual Fuel Engines. Waste and Biomass Valorization 2: $1-11$.

4. Yaliwal VS, Banapurmath NR, Gireesh NM, Tewari PG (2014) Production and utilization of renewable and sustainable gaseous fuel for power generation applications: A review of literature. Renewable and Sustainable Energy Reviews 34: 608-627.

5. Yaliwal VS, Banapurmath NR, Daboji SR, Tewari PG (2010) Production and Utilization of Renewable Liquid Fuel in a Single Cylinder Four Stroke Direct Injection Compression Ignition Engine. International Journal of Engineering Science and Technology 2: 5938-5948.
6. Olsson JO, Per T, Göran H, Bengt J (2001) A Turbo Charged Dual Fuel HCCl Engine, Society of Automotive Engineers.

7. Claudio C, Daniel B (2013) IMO Tier 3: Gas and Dual Fuel Engines as a Clean and Efficient Solution PAPER NO.: 187, International Council on Combustion Engines, CIMAC Congress 2013, Shanghai, Switzerland

8. Singh RN, Singh SP, Pathak BS (2007) Investigations on Operation of $\mathrm{C}$ Engine Using Producer Gas and Rice Bran Oil in Mixed Fuel Mode. Renewable Energy 32: 1565-1580.

9. Samir JD, Lalit BB, Shashikant BT (2008) Investigation on performance and emission characteristics of $\mathrm{Cl}$ engine fueled with producer gas and esters of Hingan (Balanites) oil in dual fuel mode. Int J Mech Syst Sci Eng 2: 148-153.

10. Banapurmath NR, Tewari PG, Yaliwal VS, Satish K, Basavarajappa YH (2009) Combustion Characteristics of a 4-Stroke $\mathrm{Cl}$ Engine Operated on Honge Oil, Neem and Rice Bran Oils When Directly Injected and Dual Fuelled with Producer Gas Induction. Renewable Energy 34: 1877-1884.

11. Ramadas AS, Jayaraj S, Muraleedharan C (2008) Dual fuel mode operation in diesel engines using renewable fuels. Rubber seed oil and coir pith producer gas. Renew Energy 339: 2077-2083.

12. Mohod AG, Gadge SR, Mandasure VN (2003) Liberation of carbon monoxide through gasifier-I.C. engine system. IE (I) J ID 84: 27-29.

13. Parikh PP, Bhave AG, Shashikantha (1987) Performance evaluation of a diese engine dual-fueled on producer-gas and diesel. In: Proceedings of the tenth national conference on IC engines and combustion. Rajkot, India, AF179AF186: 1-10.

14. Roy MM, Tomita Eiji, Kawahara N, Harada Y, Sakane A (2009) Performance and emission comparison of a supercharged dual-fuel engine fueled by producer gases with varying hydrogen content. Hydrog Energy 34: 7811-7822.

15. Hassan S, Zainal ZA, Miskam MA (2011) Effects of advanced injection timing on performance and emission of a supercharged dual-fuel diesel engine fuelled by producer gas from downdraft gasifier. Sci Ind Res 70: 220-224. 